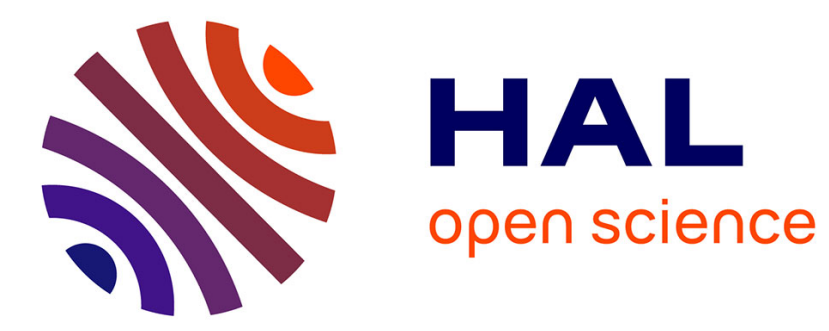

\title{
Microbeam XAFS Studies on Fluid Inclusions at High Temperatures
}

\author{
R. Mayanovic, A. Anderson, S. Bajt
}

\section{To cite this version:}

R. Mayanovic, A. Anderson, S. Bajt. Microbeam XAFS Studies on Fluid Inclusions at High Temperatures. Journal de Physique IV Proceedings, 1997, 7 (C2), pp.C2-1029-C2-1030. 10.1051/jp4:19972129 . jpa-00255189

\section{HAL Id: jpa-00255189 https://hal.science/jpa-00255189}

Submitted on 1 Jan 1997

HAL is a multi-disciplinary open access archive for the deposit and dissemination of scientific research documents, whether they are published or not. The documents may come from teaching and research institutions in France or abroad, or from public or private research centers.
L'archive ouverte pluridisciplinaire HAL, est destinée au dépôt et à la diffusion de documents scientifiques de niveau recherche, publiés ou non, émanant des établissements d'enseignement et de recherche français ou étrangers, des laboratoires publics ou privés. 


\title{
Microbeam XAFS Studies on Fluid Inclusions at High Temperatures
}

\author{
R.A. Mayanovic, A.J. Anderson* and S. Bajt**
}

Department of Physics and Astronomy, Southwest Missouri State University, Springfield, MO 65804, U.S.A.

* Department of Geology, St. Francis Xavier University, Antigonish, Nova Scotia, B2G 1CO, Canada

** Lawrence Livermore National Laboratory, Livermore, CA 94550, U.S.A.

\begin{abstract}
Zn}$ and Fe K-edge microbeam XAFS measurements have been made on individual fluid inclusions in quartz at temperatures ranging from $25^{\circ} \mathrm{C}$ to $500^{\circ} \mathrm{C}$. Analysis of $\mathrm{Zn} \mathrm{K}$-edge XAFS spectra shows that the $\mathrm{ZnCl}_{4}{ }^{2-}$ complex is predominant at all temperatures up to and including $430^{\circ} \mathrm{C}$. The $\mathrm{Zn}-\mathrm{Cl}$ bond length was found to decrease uniformly with temperature, up to nearly $2 \%$ at $430{ }^{\circ} \mathrm{C}$ in comparison to the value at $25^{\circ} \mathrm{C}$. The iron ion appears to be predominantly hydrated up to some temperature between $100^{\circ} \mathrm{C}$ and $200^{\circ} \mathrm{C}$. Above $200^{\circ} \mathrm{C}$, iron in the inclusions is predominantly coordinated by chlorine ligands.
\end{abstract}

\section{INTRODUCTION}

There is a significant lack of understanding concerning the molecular structure of metal complexes in hydrothermal environments leading up to and above supercritical conditions. Fluid inclusions, which are microscopic pockets of fluid trapped in host crystals that grew from the same but enriched fluid at elevated pressures and temperatures, are ideally suited for temperature-dependent studies on coordination and structure of complexed and/or hydrated metal ions in hydrothermal fluids using XAFS. Such studies, while of direct importance to understanding hydrothermal processes involving transport of metals within the earth's crust, [1] also have relevance to such areas as nuclear waste disposal [2]. In this paper, we discuss our investigations on the structure of zinc complexes and some preliminary findings on the coordination and surrounding structure of iron ions in fluid inclusions as a function of temperature ranging from $25^{\circ} \mathrm{C}$ to $500^{\circ} \mathrm{C}$.

\section{EXPERIMENT}

Temperature-dependent $\mathrm{Zn}$ and Fe K-edge XAFS spectra were collected in the fluorescence mode from individual fluid inclusions (averaging $\sim 60 \mu \mathrm{m}$ across and $\sim 5 \mu \mathrm{m}$ below the surface) in quartz, using a $30 \mathrm{~mm}^{2} \mathrm{Si}(\mathrm{Li})$ energy dispersive detector at beamline X26A at the NSLS. The NSLS x-ray storage ring was operated at $2.54 \mathrm{GeV}$ and between 130 to 230 $\mathrm{mA}$ of beam current. A single Si(111) channel-cut crystal and a $8: 1$ ellipsoidal Al (Pt coated) mirror were used to

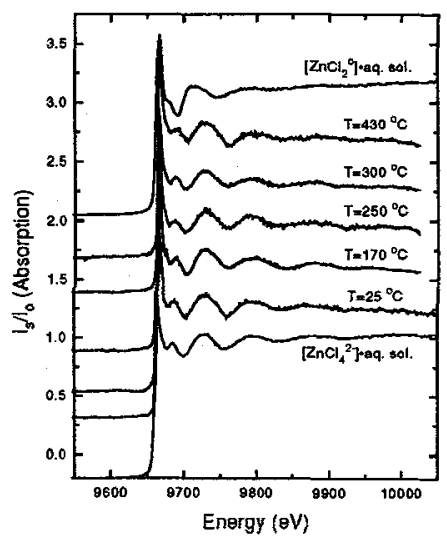

Figure 1: Zn K-edge XAFS spectra measured from an inclusion in quartz at temperatures ranging from $25^{\circ} \mathrm{C}$ to 430 ${ }^{\circ} \mathrm{C}$ and from zinc chloride $\left(\mathrm{ZnCl}_{2}{ }^{\circ}\right.$ and $\mathrm{ZnCl}_{4}{ }^{2}$, separately) aqueous solutions at room temperature.

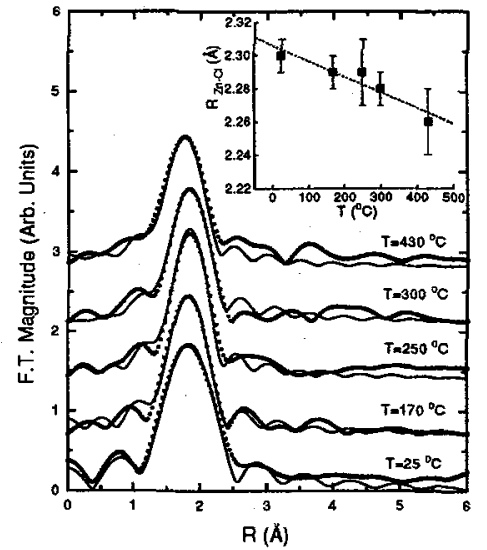

Figure 2: The magnitude of the Fourier transforms (FT) of the $k^{2} \chi$ data (points) obtained from the spectra shown in Figure 1 and of the fittings (solid lines) of this data, made using FEFF6 and a $\mathrm{ZnCl}_{4}{ }^{2-}$ model. The inset shows the results for the $\mathrm{Zn}-\mathrm{Cl}$ bond lengths of the $\mathrm{ZnCl}_{4}{ }^{2-}$ complex in the inclusions as a function of temperature. 
monochromatize and focus the $\mathrm{x}$-rays, respectively. Fine collimating slits and a pinhole mask were used to produce a $30 \mu \mathrm{m}$ wide $\mathrm{x}$-ray beam at the sample. The quartz samples were extracted from a pegmatite dyke intruding into granulites of the Saxon Granulite Massif, Germany. At room temperature, the inclusions typically contain a saline aqueous solution (containing ppm concentrations of $\mathrm{Zn}, \mathrm{Fe}, \mathrm{Pb}$, etc.), a vapor bubble, and a halite crystal. The XAFS spectra were analyzed by fitting the Fourier transform (FT) data using theoretical spectra generated with FEFF6 [3]. Additional experimental details can be found elsewhere [4].

\section{RESULTS AND DISCUSSION}

Figure 2 shows excellent agreement between the Fourier transforms of the XAFS spectra and the theoretical data generated using FEFF6. Analysis of the data indicates that the dominant zinc complex in the inclusions at all temperatures ranging from $25^{\circ} \mathrm{C}$ to $430^{\circ} \mathrm{C}$ is $\mathrm{ZnCl}_{4}^{2-}$. This is evidenced by our results showing the coordination number (for $\mathrm{Cl}$ ) as being very close to four for all temperatures ranging from $25^{\circ} \mathrm{C}$ to $430{ }^{\circ} \mathrm{C}$. The $\mathrm{Zn}$ - $\mathrm{Cl}$ mean-square relative displacement $\sigma^{2}$ (MSRD) in the Debye-Waller approximation increased uniformly with temperature, from a value of $0.0043 \AA^{2}$ at $25^{\circ} \mathrm{C}$ to $0.0089 \AA^{2}$ at $430^{\circ} \mathrm{C}$. It was only necessary to include the third $\left(C_{3}\right)$ and fourth $\left(C_{4}\right)$ order terms in the cumulant expansion in the fitting of the spectra for the two highest temperatures (e.g. $C_{3}=3.8 \times 10^{-4} \AA^{3}$ and $C_{4}=2.9 \times 10^{-5} \AA^{4}$ at $430{ }^{\circ} \mathrm{C}$ ). The clear dominance of $\mathrm{ZnCl}_{4}{ }^{2-}$ in the inclusions at high temperatures is somewhat surprising in light of results from solubility and spectroscopic studies on aqueous solutions (having $<5 \mathrm{~mol} / \mathrm{kg} \mathrm{Cl}$ ) showing that metal complex ligation numbers decrease with increasing temperature, with a trend toward charge neutrality [2]. This difference can in part be attributed to the high chloride concentration of the inclusions (est. up to $9 \mathrm{~mol} / \mathrm{kg}$ ). In addition, it is not known to what extent chemical factors such as $\mathrm{pH}$ of the fluid and fugacity of volatiles $\left(\mathrm{CO}_{2}, \mathrm{H}_{2}\right.$, etc.) may affect zinc chloride complex stability in the inclusions.

The $\mathrm{Zn}-\mathrm{Cl}$ bonds of the $\mathrm{ZnCl}_{4}{ }^{2-}$ complex were found to exhibit a reduction in length (by nearly $2 \%$ at $430{ }^{\circ} \mathrm{C}$ compared to the value at $25^{\circ} \mathrm{C}$ ) with temperature (Figure 2). Similar results have been reported for the first hydration shell of $\mathrm{Rb}^{+}$in aqueous solutions [5]. The pressure in the fluid inclusions, which increased from perhaps a couple of hundred bars at $25^{\circ} \mathrm{C}$ to roughly 500 bars at $430^{\circ} \mathrm{C}$, can only account for a very small amount of the bond contraction. We speculate that the contraction of the $\mathrm{Zn}-\mathrm{Cl}$ bond length is due to a progressive reduction of the dielectric constant of the liquid phase, leading to enhanced $\mathrm{Zn} 3 \mathrm{~d}\left(\mathrm{t}_{\mathrm{g}}\right)$ and $\mathrm{Cl} 3 \mathrm{p}$ orbital interaction at the complex site with temperature and resulting in a greater repulsion between $t_{2 \mathrm{~g}}$ and $\mathrm{e}_{\mathrm{g}}$ bonding versus antibonding molecular orbitals. Another possibility is that the $\mathrm{ZnCl}_{4}{ }^{2-}$ complex becomes increasingly more dehydrated with temperature, resulting in stronger $\mathrm{Zn}-\mathrm{Cl}$ bonding and thus a contraction of the bond length [6].

Preliminary results from fitting of the Fourier transforms of the Fe K-edge

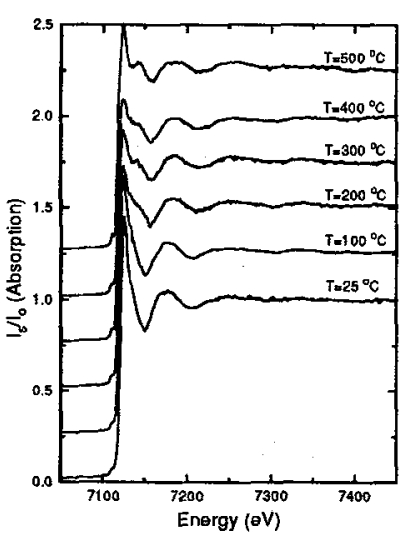

Figure 3: Fe K-edge XAFS spectra measured from an inclusion in quartz at temperatures ranging from $25^{\circ} \mathrm{C}$ to 500 ${ }^{\circ} \mathrm{C}$. spectra shown in Figure 3 indicate that the iron ion is predominantly hydrated from $25^{\circ} \mathrm{C}$ to $100^{\circ} \mathrm{C}$ and probably somewhat above this temperature. The $\mathrm{Fe}-\mathrm{O}$ distance was close to $2.10 \AA$ with roughly six water molecules in the first hydration shell at both temperatures. At $200^{\circ} \mathrm{C}$ and above (to $500^{\circ} \mathrm{C}$ ), the iron ion is predominantly coordinated by the chlorine ligands. This coincides rather nicely with complete dissolution of the halite $(\mathrm{NaCl})$, which typically occurs at about $260^{\circ} \mathrm{C}$, indicating that substantially more $\mathrm{Cl}$ ions become available for bonding with iron. There is a progressive change with temperature, from $200^{\circ} \mathrm{C}$ to $500^{\circ} \mathrm{C}$, in the near edge region of the spectra, indicating that the nature of the iron chloro complex may change with temperature. It is possible that a mixture of several different types of iron chloro complexes coexist in the inclusions, with their relative concentrations changing with temperature. The average number of chlorine ligands increased uniformly from roughly three at $200^{\circ} \mathrm{C}$ to four at $500^{\circ} \mathrm{C}$. Conversely, just as for the $\mathrm{Zn}-\mathrm{Cl}$ bond length, the $\mathrm{Fe}-\mathrm{Cl}$ bond length decreased uniformly from $2.29 \AA$ at $200{ }^{\circ} \mathrm{C}$ to $2.25 \AA$ at $500^{\circ} \mathrm{C}$. However, because of the possiblity of admixture of several types of iron complexes, these values may reflect average bond lengths and, therefore, may not reflect uniform bond contraction with temperature for any one type of iron chloro complex in the inclusions. Further analysis of the data should help resolve these and other questions regarding the nature of iron complexes at elevated temperatures in hydrothermal environments.

\section{References}

[1] H.L. Barnes, Geochemistry of Hydrothermal Ore Deposits (Wiley, New York, 1979) 404.

[2] J.A. Ruaya and T.M. Seward, Geochim. Cosmochim. Acta. 50 (1986) 651.

[3] J. Mustre de Leon, J.J. Rehr, S.I. Zabinsky, and R.C. Albers, Phys. Rev. B 44 (1991) 4146

[4] R.A. Mayanovic. A.J. Anderson, and S. Bajt, Physica B Physica B 208 \& 209 (1995)239: A.J. Anderson, R.A. Mayanovic, and S. Bajt, Can. Mineral. 33 (1995) 499.

[5] J. L. Fulton, D.M. Pfund, S.L. Wallen, M. Newville. E.A. Stern, and Y. Ma, J. Chem. Phys. (in press).

[6] E.D. Glendening and D. Feller, J. Phys. Chem. 99 (1995) 3060. 